\title{
Pergeseran Model Pendampingan Penggunaan Media Digital oleh Orangtua pada Anak di Masa Pandemi COVID-19
}

\author{
Syifa Syarifah Alamiyah ${ }^{1}$, Ade Kusuma ${ }^{2}$, Juwito Juwito ${ }^{3}$, Didiek Tranggono ${ }^{4}$ \\ 1,2,3,4 Communication Sciences Department, Faculty of Social and Political Sciences \\ Universitas Pembangunan Nasional Veteran Jawa Timur, Surabaya, Indonesia \\ Contact: syifa_syarifah.ilkom@upnjatim.ac.id
}

\begin{abstract}
As an effort to control and handle COVID-19, the government has issued a school from home (SFH) policy. This policy has forced children to stay at home and carry out learning using digital media. This situation has an impact on increasing the use of digital media and the involvement of parents in children's learning significantly. This study explores the use of digital media in children in Surabaya during the pandemic period and how parents can assist the use of these media. This research uses qualitative methods with in-depth interview techniques. Researchers distributed questionnaires about the use of digital media to 66 parents, and nine parents stated that they were willing to become informants. The results show that in addition to a significant increase in the time to use digital media during the pandemic, the pandemic has also changed the parental assistance and supervision of children. Before the pandemic, the assistance model was carried out more with technical restrictions, in the form of time restrictions, content access, application choices, and the number of data packages (restrictive mediation). However, during a pandemic, the mentoring model was carried out with active mediation through discussions and critical thinking, active together with devices, close surveillance, and monitoring on applications and post online activities (active mediation, co-using, supervision, monitoring). One of the pandemic's positive impacts is the opening of discussion spaces between parents and children, the opportunity to use gadgets together, and opportunities for children and parents to learn digital skills.
\end{abstract}

Keywords: COVID-19, digital media and children, parental mediation.

\section{ABSTRAK}

Sebagai upaya penanggulangan dan penanganan COVID-19, pemerintah telah mengeluarkan kebijakan sekolah dari rumah atau School From Home (SFH). Kebijakan ini telah memaksa anak-anak untuk tetap berada di rumah dan melaksanakan pembelajaran dengan menggunakan media digital. Kondisi ini berdampak pada peningkatan penggunaan media digital secara signifikan dan peningkatan keterlibatan orangtua dalam pembelajaran. Penelitian ini bertujuan untuk mengeksplorasi penggunaan media digital pada anak-anak di Surabaya selama masa pandemi dan bagaimana orangtua mendampingi penggunaan media tersebut. Penelitian ini menggunakan metode kualitatif dengan teknik wawancara mendalam. Peneliti menyebarkan kuesioner tentang penggunaan media digital kepada 66 orangtua, dan sebanyak 9 orangtua menyatakan bersedia menjadi informan. Hasil penelitian menunjukan bahwa selain terjadi peningkatan waktu penggunaan media digital secara signifikan selama masa pandemi, pandemi turut mengubah pola pendampingan dan pengawasan oleh orangtua kepada anak. Jika sebelum pandemi, model pendampingan lebih dilakukan dengan pelarangan dan pembatasan teknis, berupa pembatasan waktu, akses konten, pilihan aplikasi, dan jumlah paket data (restrictive mediation). Namun pada masa pandemi, model pendampingan dilakukan dengan mediasi aktif melalui diskusi dan ajakan berpikir kritis; penggunaan gawai bersamasama secara aktif; pengawasan dari dekat; dan monitoring pada aplikasi dan parangkat pasca aktivitas daring (active mediation, co-using, supervision, monitoring). Salah satu dampak positif pandemi adalah terbukanya ruang diskusi antara orangtua dan anak, terjadinya kesempatan menggunakan gawai secara bersama, dan terbuka peluang bagi anak dan orangtua mempelajari keterampilan digital.

Kata Kunci : COVID-19; anak dan media digital; pendampingan media. 


\section{Pendahuluan}

Pandemi COVID-19 telah menyebabkan perubahan pada berbagai aspek kehidupan manusia. Untuk mengatasi dan mengurangi dampak resiko pandemi, pemerintah memberlakukan pembelajaran secara daring yang dilakukan melalui media digital dari rumah. Kegiatan pembelajaran yang sebelumnya terpusat di sekolah, di alihkan ke rumah. Proses pembelajaran yang sebelumnya berlangsung melalui pertemuan langsung tatap muka, berubah menjadi pembelajaran daring. Terdapat dua hal yang signifikan dalam pembelajaran di rumah di masa pandemi, yaitu penggunaan teknologi digital secara intensif dan keterlibatan orangtua. Seperti halnya diungkapkan oleh Livari, Sharma \& Venta-Olkkonen bahwa pandemi telah menginisiasi transformasi digital yang extensive, tiba-tiba dan dramatis dalam kehidupan bermasyarakat (2020). Pada masa sebelum pandemi media digital yang awalnya lebih banyak digunakan untuk keperluan konektivitas dan hiburan, saat ini media digital digunakan sebagai media utama pendukung pelaksanaan pembelajaran. Dalam kondisi demikian, orang tua memiliki peran sentral dalam melakukan pendampingan, karena beralihnya pembelajaran dari sekolah ke rumah (Lau \& Lee, 2020).

Pelaksanaan School From Home (SFH) telah mengubah landskap penggunaan media dalam kehidupan keluarga (Livingstone, 2020; Saptyasari, 2020). Media digital digunakan secara ekstensif untuk keperluan pendidikan dengan rentang waktu yang cukup panjang (Wiederbold, 2020; Wong, Tsai, Jonas, Ohno-Matsui, Chen, Ang, Ting, 2020) dalam berbagai aktifitas khususnya untuk pendidikan dan pekerjaan orangtua. Padahal sebelum masa pandemi pun tingkat penggunaan media digital di kalangan anak-anak yang merupakan digital natives sudah cukup tinggi (Hendriyani, Hollander, d'Haenens, \& Beentjes, 2012). Ketika memasuki pandemi, durasi penggunaan media digital pada anak meningkat signifikan (Lau \&Lee, 2020; Miranda, Athanasio, Oliveira, Simoes-e-Silva, 2020; Wiederhold, 2020). Alamiyah, Zamzamy, dan Rasyidah (2017) menyatakan bahwa jumlah jam yang digunakan anak Indonesia untuk menonton televisi mencapai 1.500 jam per tahun sedangkan jumlah waktu yang dihabiskan di sekolah adalah 750 jam per tahun. Peningkatan penggunaan perangkat digital pada anak, cepat terjadi karena anak-anak cenderung multitasking ketika menggunakan perangkat digital (Shin \& Li, 2016).

Perhatian yang tinggi mengenai hubungan antara anak-anak, media serta orangtua, telah menginspirasi berbagai penelitian tentang peran media dalam kehidupan anak-anak dan peran orangtua dalam penggunaan media anak. Penelitian yang dilakukan Brito, Fransisco, Dias, \& Chaudron (2017) pada keluarga di 14 negara Eropa dengan anak usia 0-8 tahun mengungkapkan bahwa terdapat empat model pendampingan media yang digunakan pada kebanyakan keluarga di Eropa, model yang paling banyak diterapkan adalah model authoritative dengan pengaturan waktu dan konten sebagai bentuk kontrol dalam pengawasan. Pendampingan penggunaan media atau yang biasa disebut dengan konsep parental mediation juga diteliti oleh Troseth, Russo, Strouse (2016) yang melihat dampak penggunaan media terhadap anak dan peran orangtua dalam mendampingi anak. Studi tersebut menyimpulkan bahwa anak-anak membutuhkan dukungan orang dewasa dalam memahami pembelajaran melaui media interaktif untuk mengembangkan kemampuan kognitif dan interaksi sosial. Hal senada dinyatakan oleh Alamiyah et al. (2019), bahwa 
pendampingan media oleh orang tua membantu anak mengembangkan keterampilan berpikir kritis dan memfasilitasi kebiasaan yang baik dan sehat dalam penggunaan media digital. Brito, Francisco, Dias \& Chaudron (2017) menyatakan bahwa orangtua juga memiliki peran yang penting dalam terpaan dan penggunaan media pada anak berusia di bawah 8 tahun, yaitu sebagai teladan dan juga sebagai gatekeeper yang menyaring akses anak terhadap berbagai media dan konten.

Konsep parental mediation ini sangat dekat dengan teori psikologis yang berkaitan dengan praktek parenting. Pada awalnya konsep parental mediation diterapkan untuk melihat terpaan dan pendampingan pada media televisi, namun pada perkembangan selanjutnya beberapa teori dan model dikembangkan berkaitan dengan pendampingan media digital (Valcke, Bonte, Wener, \& Rots, 2010). Beberapa model pendampingan media telah diajukan juga oleh para ahli, salah satunya model yang dikemukakan oleh Livingstone dan Bober (2004) yang membedakan dimensi "material" dan dimensi "simbolis" dari pendampingan media. Dimensi yang pertama merujuk pada sejauh mana orangtua menggunakan teknologi dan mempromosikan akses terhadap perangkat digital dan dimensi kedua merujuk pada promosi dan dukungan terhadap praktik dan pengaturan teknologi digital serta negosiasi mengenai peraturan.

Dalam penelitian lainnya Livingstone dan Helsper (2010) menyimpulkan beberapa model orangtua dalam melakukan pendampingan terhadap penggunaan media pada anak, diantaranya yaitu 1) menerapkan aturan mengenai waktu dan konten (restrictive mediation). 2) active mediation atau pendampingan aktif melalui diskusi, untuk meningkatkan keamanan dengan menumbuhkan kemampuan berpikir kritis 3). Co-using atau penggunaan bersamasama secara aktif untuk tujuan hiburan atau pendidikan, 4) supervision atau pengawasan misal dengan berada di dekat anak-anak untuk mengawasi apa yang dilihat oleh anak, 5) melakukan monitor setelah anak-anak melakukan aktifitas online dengan melakukan pengecekan pada aplikasi atau perangkat 6) Menggunakan pembatasan teknis, seperti memanfaatkan aplikasi kontrol orang tua yang tersedia pada perangkat digital atau dengan mengunduh aplikasi tertentu untuk mengatur atau memblokir konten yang dianggap tidak pantas.

Lebih lanjut Brito et al., (2017) menjelaskan empat model parental mediation yang dikaitkan dengan model gaya pengasuhan, yaitu dengan melihat penggunaan media berdasarkan kontrol orangtua terhadap penggunaan media dan kehangatan orangtua. Model ini terdiri dari authoritative, dimana orangtua menerapkan dan menjelaskan seperangkat aturan kepada anak sehingga menumbuhkan tanggung jawab dan regulasi mandiri dari anak, seperti misalnya menerapkan aturan mengenai konten dan waktu dalam menggunakan media. Gaya yang kedua adalah authoritarian, dimana orangtua menerapkan aturan tanpa menjelaskannya tetapi disisi lain mengharapkan anak untuk patuh terhadap aturan tersebut, tanpa dialog, dan memaksakan persepsi orantua sendiri terhadap media. Selanjutnya adalah permissive, yaitu orangtua tidak menerapkan aturan yang jelas mengenai pengunaan media tetapi memonitor penggunaan media dan bernegosasi dengan anak, membimbing dan mengajarkan secara terbatas, cenderung bereaksi ketika terdapat permintaan dari anak. Yang terakhir adalah laissez-faire, dimana orang tua membebaskan dan tidak melakukan intervensi 
sama sekali terhadap pengunaan gadget pada anak. Dalam penelitiannya terhadap keluarga di 14 negara Eropa, Brito et al. (2017) menemukan bahwa model pendampingan penggunaan media yang paling banyak dilakukan adalah model authoritative. la juga melihat terdapat perbedaan gaya antara pendampingan yang dilakukan oleh ayah dan ibu. Model yang diadaptasi oleh para ibu cenderung authoritatif, dengan menerapkan kontrol yang ketat namun juga memberikan kehangatan yang intens, sementara ayah cenderung menerapkan model authoritarian, dengan kontrol yang ketat dan tingkat kehangatan yang lebih rendah dibandingkan ibu. Temuan lainnya adalah bahwa orangtua cenderung menerapkan aturan yang lebih longgar terhadap anak laki-laki namun lebih ketat terhadap anak perempuan (Brito, 2017).

Penelitian ini bertujuan untuk mengeksplorasi model pendampingan media yang dilakukan orang tua selama masa pandemi di Surabaya. Termasuk mendapatkan informasi dari orangtua tentang kebiasaan penggunaan media digital oleh anak-anak (media habit), jenis aplikasi apa digunakan, jenis konten yang sering diakses, jenis ketrampilan media yang dikembangkan, serta motif pemilihan aplikasi dan konten.

\section{Metode}

Penelitian menggunakan metode kualitatif dengan tujuan untuk mengungkap bagaimana media digital digunakan pada keluarga di Surabaya dan bagaimana orangtua menerapkan pendampingan penggunaan media pada anak selama masa pandemi. Pengumpulan data dilakukan melalui kuesioner daring dengan google form dan wawancara mendalam secara daring dan tatap muka (dengan mematuhi protokol Kesehatan). Awal pemilihan informan dilakukan dengan penyebaran pesan singkat melalui aplikasi Whatsapp ke beberapa grup orangtua wali siswa sekolah dasar di Surabaya. Akses ke grup ini didapatkan dari kontak personal yang dimiliki oleh tim peneliti. Tercatat ada 66 orangtua murid yang memberikan response dengan mengisi questioner melalui link google form. Dari jumlah 66 orang tua murid yang mengisi quesioner, tim peneliti menentukan sembilan orangtua murid yang memenuhi kriteria sebagai informan yaitu, (1) tinggal di Kota Surabaya, (2) memiliki anak usia 1-15 tahun, (3) aktif menggunakan media digital, (4) memiliki pengalaman berbagi gawai untuk digunakan bersama.

Sembilan orang yang menjadi informan adalah para ibu berusia antara 25 sampai 50 tahun yang memiliki anak berusia antara 1 tahun hingga 15 tahun. Tingkat pendidikan para informan yang terendah adalah lulusan SMA dan yang tertinggi bergelar doktor. Latar belakang pekerjaannya sangat beragam, yaitu pengusaha katering, penjual kue dan roti, pemilik toko online, pengajar, psikolog, dan staf keuangan. Seluruh informan terampil dalam menggunakan media digital karena berkaitan dengan pekerjaan mereka sehari-hari.

Analisis data dilakukan sejak berlangsungnya proses pengumpulan data hingga setelah semua data selesai dikumpulkan. Setelah melakukan reduksi pada informasi yang tidak relevan, dilanjutkan dengan pemilahan kategori model pendampingan media, selanjutnya tim peneliti memberikan interpretasi data menggunakan berbagai model pendampingan media dan gaya pengasuhan anak. 


\section{Hasil dan Pembahasan}

Selama masa pandemi COVID-19, intensitas penggunaan media digital meningkat signifikan (Wong, Ming, Maslow, \& Gifford, 2020; Cellini, Canale, Mioni, \& Costa, 2020; Wiederhold, 2020). Peningkatan intensitas dan durasi penggunaan media digital selama pandemi (Indiyati, Khusnia \& Khotijah, 2020), mengakibatkan berubahnya pola penggunaan media dalam keluarga serta pola pendampingan orangtua dalam penggunaan media. Seluruh keluarga informan melakukan penyesuaian dalam hal durasi penggunaan media digital. Sebelum pandemi, durasi penggunaan media digital oleh anak-anak di rumah hanya berkisar antara 2-4 jam. Namun disaat pandemi anak, durasinya penggunaan media digital (smartphone dan laptop) meningkat hingga 8 jam sehari. Anak-anak umumnya hanya diperbolehkan menggunakan smartphone pada saat pulang sekolah dan waktu senggang.

Anak-anak sekolah di Surabaya, sebelum masa pandemi, lebih banyak memanfaatkan smartphone sebagai media hiburan dan sarana berkomunikasi dengan teman, keluarga maupun guru. Ketika memasuki pandemi, smartphone lebih banyak digunakan untuk mengikuti pelajaran sekolah. Rata-rata waktu pelajaran dalam sehari adalah enam jam, belum termasuk pengerjaan tugas dan konsultasi dengan guru dan teman sekelas. Apabila ditambahkan dengan kebutuhan informasi dan hiburan, maka durasi waktu minimal yang digunakan oleh anak-anak adalah delapan jam sehari. Padahal anak-anak sangat membutuhkan pembatasan waktu untuk menggunakan media digital (AAP Council on Communication and Media, 2016).

Anak-anak berusia di bawah delapan tahun masih memerlukan bantuan orangtua untuk menyiapkan peralatan sekolah dan perangkat digital yang digunakan untuk keperluan SFH. Orangtua memilih untuk selalu mendampingi dan mengawasi selama proses pembelajaran, untuk berjaga-jaga apabila anak-anak mereka membutuhkan bantuan. Sedangkan anak-anak yang berusia di atas delapan tahun, sudah mampu menyiapkan dan mengoperasikan sendiri media digital (smartphone dan laptop) dan aplikasi pembelajaran (Zoom dan google meet) untuk keperluan SFH. Sedangkan orangtua hanya sesekali mengawasi proses belajar daring dan memastikan konsentrasi anak-anak dalam mengikuti pembelajaran, agar tidak membuka youtube atau aplikasi lain ketika pelajaran berlangsung.

Selama SFH, aktivitas rutin para orangtua adalah memastikan anak-anak untuk: bangun tepat waktu, membersihkan diri, dan sarapan sebelum pembelajaran daring. Seluruh orangtua berusaha menyiapkan suasana santai, menyenangkan, dan meminimalkan gangguan selama pembelajaran online. Orangtua yang memiliki anak berusia dibawah delapan tahun mengaku turut mengerjakan tugas sekolah anaknya. Berbeda dengan orangtua yang memiliki anak berusia di atas delapan tahun, mengakui tidak perlu membantu pengerjaan tugas sekolah anak mereka.

"Anak saya masih berusia tujuh tahun dan belum mandiri, jadinya ya Saya harus bantu mengerjakan tugas sekolahnya. Kalau tidak saya bantu, tugasnya masih sering keliru dan tidak selesai tepat waktu. Tidak semua tugas saya bantu, kadang Saya memotivasinya untuk mengerjakan sendiri soal dan tugas yang harus selesai dikerjakan saat daring." (Wawancara JN, pemilik usaha catering, umur 30 tahun). 
Sebagaimana penelitian Venta-Olkkonenn (2020), bahwa anak-anak berusia dibawah delapan tahun masih memiliki ketergantungan terhadap saudara yang lebih besar atau orangtua untuk melakukan pembelajaran daring, karena mereka belum sepenuhnya memiliki kemampuan dalam mengoperasikan perangkat digital, mereka perlu dibantu untuk terhubung dalam proses pembelajaran online. Uniknya, anak-anak yang berusia di atas delapan tahun mempunyai kemampuan yang cepat dalam beradaptasi dengan metode dan perangkat pembelajaran daring seperti keterampilan mengoperasikan Zoom, Google Classroom, dan Google Meet. Serta cakap menjalankan aplikasi Words, Excell, dan Power Point.

Kebutuhan media digital di masa pandemi menjadi sangat penting bagi seluruh keluarga informan. Sebagai orangtua, mereka menyediakan setiap anaknya untuk memiliki perangkat digital sendiri untuk keperluan SFH. Meskipun berasal dari latar belakang ekonomi menengah, orangtua berusaha menyediakan smartphone sederhana agar anak-anak mereka tetap dapat mengikuti pembelajran daring.

"Saya punya tiga orang anak, semuanya bersekolah. Dua orang masih SD, yang paling besar sudah SMP. Pada awal pandemi, saya hanya sediakan satu smartphone untuk dipakai bergantian mengkuti pembelajaran daring. Maksud saya agar anakanak tidak berlebihan waktunya menggunakan HP. Tetapi semakin kesini, menggunakan HP untuk sekolah daring bergantian kok menjadi mustahil. Saya terpaksa menyediakan uang ekstra untuk membelikan HP untuk tiga anak saya." (Wawancara ST, penjual kue dan makanan kecil, umur 36 tahun).

Ketersediaan jaringan internet menjadi permasalahan penting seluruh informan, karena menjadi faktor kunci bagi lancarnya proses pembelajaran daring selama pandemi. Seluruh informan mengakui bahwa penting untuk menyediakan fasilitas wi-fi di rumah, meskipun dibutuhkan biaya ekstra untuk pemasangan perangkat dan biaya langganannya.

\begin{abstract}
"Sebelum pandemi, keluarga Saya hanya mengandalkan pembelian pulsa untuk paket data di HP saya, suami dan anak-anak. Tetapi karena tidak ada pembelajaran tatap muka, sekolah dan kampus tutup, maka keluarga Saya memutuskan melakukan upgrade fasilitas wi-fi di rumah dari kecepatan 10 Mbps menjadi 20 Mbps unlimited. Dua anak saya kuliah dan satu anak masih SMP, ketiganya butuh koneksi internet. Sedangkan saya tidak bisa lagi mengajar ke kampus karena harus Work From Home. Suami saya pun mendapatkan giliran piket kerja, jadi tidak setiap hari ngantor. Alokasi budget untuk pembelian pulsa kami alihkan untuk biaya abonemen. Meskipun Saya dan anak-anak mendapat jatah kuota gratis dari pemerintah tapi itu tidak cukup." (Wawancara YC, dosen PTN, umur 48 tahun).
\end{abstract}

Aplikasi dan konten yang diakses melalui media digital oleh anak-anak laki-laki dan perempuan memiliki perbedaan. Bagi anak-anak perempuan jika mengakses Youtube, mereka memilih konten musik dan film. Bagi anak-anak laki-laki jika mengakses Youtube, mereka memilih konten games dan olahraga. Kesamaan yang ada adalah pada konten acara televisi tentang pemilihan calon penyanyi dan memasak. Pada pilihan konten hiburan, anak laki-laki dan perempuan juga berbeda. Terkait pilihan games online, anak-anak laki-laki memilih games: Mobile Legends, PUBG Mobile, dan Free Fire. Anak-anak perempuan lebih menyukai games: Gatcha life, Sakura School, 8-Ball Pool, dan Growtopia. Sedangkan aplikasi pesan yang paling 
banyak diakses anak-anak perempuan adalah WhatsApp, Telegram, dan Direct Messages melalui Instagram. Sedangkan anak-anak laki-laki banyak menggunakan WhatsApp, Line dan Direct Messages melalui Instagram. Anak-anak membuat grup dengan topik berbeda-beda untuk tetap berinteraksi dalam kelompok dengan minat yang sama. Grup-grup tersebut terdiri dari grup teman sekolah, grup teman sepermainan, grup kelas, grup tugas sekolah, dan grup ekstra kurikuler. Aplikasi media sosial yang paling populer bagi anak-anak usia 6-15 tahun adalah Instagram dan Tik Tok.

Keberadaan orangtua dalam mengawasi anak-anaknya menggunakan media digital bukan berarti orangtua memahami batasan rating aplikasi yang dipasang (install) di dalam perangkat HP anak-anak. Orangtua mengaku tidak masalah apabila anak-anak yang berusia lebih muda untuk mengakses aplikasi secara bersama dengan saudaranya yang lebih tua. Terbukti ada tiga anak perempuan berusia antara 4 hingga 6 tahun mengakses aplikasi Likee, Tiktok, dan Hago dengan kakak-kakaknya.

"Saya kurang memahami rating aplikasi yang ada di HP anak perempuan saya. Saya tahunya, putri saya yang berumur 5 tahun bermain Hago dengan kakak-kakaknya yang SMP. Saya kira tidak apa-apa, toh mereka hanya bermain-main saja. Saya malah baru tahu dari peneliti, bahwa rating aplikasi dibuat untuk menyesesuaikan dengan umur penggunanya. Saya juga baru tahu kalau aplikasi Hago diperuntukkan bagi anak berusia 12 tahun ke atas." (Wawancara RF, pemilik toko online, umur 35 tahun).

Dalam hal perkembangan aplikasi, anak-anak lebih mengikuti trend mengenai aplikasi dan konten-konten terbaru, sementara orang tua tidak terlalu mengikuti aplikasi apa saja yang sedang trend dan sedang disukai oleh anak-anak. Hanya beberapa orangtua yang mengikuti perkembangan sesuai dengan perkembangan anak. Begitupula dengan keterampilan teknologi informasi dan komunikasi, skill anak-anak cenderung lebih cakap bila dibandingkan ibunya, kecuali yang orangtuanya bekerja menggunakan teknologi digital. Hal ini sejalan dengan penelitian Hendriyani, Hollander, d'Haenens \& Beentjes (2014) yang menemukan bahwa orangtua memiliki kesadaran dan keterlibatan yang terbatas pada media yang lebih baru, selain itu orangtua juga cenderung tidak terlibat dalam kegiatan digital anak-anak karena sebagian besar orangtua belum mempunyai keterampilan literasi komputer.

Rendahnya kesadaran orangtua terhadap jenis konten dan aplikasi yang diakses dimungkinkan karena rendahnya kesadaran orangtua terhadap potensi bahaya yang dapat ditimbulkan dari paparan internet. Sebagaimana diakui oleh informan berinisial JE berikut ini:

"Saya tidak melihat adanya bahaya dalam internet kecuali dampak negatif terhadap kesehatan dan mengakibatkan anak menjadi lalai. Seperti lalai terhadap tugas dan kesehatan serta membuat anak menjadi lambat dalam merespon permintaan orangtua karena anak terlalu terikat dengan perangkat digital. Saya termasuk orangtua yang percaya bahwa internet yang di akses melalui perangkat digital menawarkan berbagai hal positif, seperti pendidikan, informasi yang bermanfaat dan menarik, serta hiburan-hiburan." (Wawancara JE, Staf Keuangan di salah satu Dinas milik Pemerintah Kota Surabaya, umur 27 tahun).

Berbeda dengan pengakuan salah satu informan berinisial PU yang berprofesi sebagai psikolog, menerapkan pembatasan longgar bagi anaknya yang berusia di atas 12 tahun. Bahwa 
yang harus diwaspadai dari penggunaan internet adalah bahaya paparan pornografi dan kesehatan mata.

"Anak saya sudah mendapatkan informasi yang cukup untuk mewaspadai kontenkonten berbahaya di internet. Yang perlu diwaspadai oleh orangtua saat ini adalah pentingnya memiliki kesadsaran terhadap potensi bahaya di dalam internet, seperti: penipuan, trafficking, kekerasan pada anak, pelecehan, dan bullying. Saya menerapkan pengawasan longgar terhadap anak-anak saya, karena saya mengajarkan tanggung jawab. Terkait konten pornografi, saya sudah memberi pendidikan bahwa pornografi merupakan hal yang tidak pantas dan tidak boleh dilihat. Saya rasa itu cukup." (Wawancara PU, Psikolog, umur 38 tahun)

Penelitian ini menemukan bahwa seluruh informan memberlakukan peraturan yang disepakati dengan anak-anak mereka dalam hal pembatasan waktu penggunaan smartphone dan pembatasan akses konten. Secara rutin para informan melakukan pengecekan history pada mesin pencari di HP anak-anak. Seluruh informan menyadari bahwa anak-anak mereka berada masa pubertas dan perjalanan menuju akil baligh. Seluruh informan secara terbuka berdiskusi dengan anak-anak mereka tentang apa yang boleh dan apa yang tidak boleh, dan mengaitkan dengan norma agama. Temuan berbeda terjadi pada penelitian Brito et al. (2017) yang menyajikan perbedaan perlakuan pembatasan penggunaan media digital, atas dasar perbedaan gender anak. Anak-anak perempuan cenderung mendapatkan pembatasan yang lebih ketat daripada anak-anak laki-laki.

Penelitian ini memperkaya temuan dari penelitian (Valkenburg, 1999), karena menyajikan temuan bahwa bentuk pendampingan orangtua pada anak dalam menggunakan media digital ini dipengaruhi oleh beberapa faktor seperti umur, tingkat pendidikan, dan gender anak. Selain faktor demografis tersebut, hal lain yang mempengaruhi perbedaan pendampingan diantaranya adalah tingkat kemampuan orang tua itu sendiri dalam menggunakan teknologi, tingkat pemahaman orangtua terhadap aplikasi dan konten, jumlah anggota dalam keluarga, dan jumlah media digital dalam rumah tersebut. Hal-hal tersebutlah yang pada akhirnya menentukan bagaimana keterlibatan orang tua dalam pendampingan penggunaan media digital anak. Hasil penelitian ini sejalan dengan temuan Kristianto (2017) bahwa orangtua memiliki peran dalam membentuk persepsi anak tentang dampak dan pola penggunaan media digital. Termasuk di dalamnya seberapa banyak orangtua mengalokasikan waktu untuk mendampingi anak dan bagaimana usaha yang dilakukan orangtua untuk mengontrol penggunaan media.

\section{Pendampingan penggunaan media pada anak di Surabaya}

Semua informan penelitian menyatakan bahwa mereka menerapkan pendampingan dengan memberikan aturan mengenai waktu dan konten yang di akses oleh anak- anak. Waktu yang diterapkan oleh para orangtua ini bervariasi, secara umum menerapkan waktu 2 jam di hari sekolah dan 2-4 jam di luar jam sekolah. Mereka mempertimbangkan alasan kesehatan anak-anak ketika menerapkan peraturan ini. Namun demikian ketika masa school from home, semua orang tua dalam studi ini menjadi lebih permisive atau longgar dalam menerapkan aturan waktu, terlebih pada anak-anak yang lebih besar. Karena orangtua menganggap bahwa 
anak-anak membutuhkan media digital untuk mendukung pembelajaran dari sekolah. Selain itu juga orang tua merasa bahwa anak-anak sudah bosan dan memiliki pergerakan yang terbatas di dalam rumah, sehingga memperbolehkan anak-anak untuk menggunakan media digital untuk emmenuhi kebutuhan hiburan, hal ini selaras dengan pendapat Wiederhold (2020) bahwa media digital di masa pandemi berperan sangat penting dalam memenuhi kebutuhan anak untuk mengakses pendidikan, berinteraksi dengan teman dan bermain. Sementara anak yang lebih kecil, di bawah 7 tahun, orang tua memberikan pembatasan waktu yang lebih ketat, karena menganggap bahwa anak-anak seusia mereka perlu lebih banyak berinteraksi dengan teman atau keluarga dibandingkan dengan media digital, dan kebutuhan mereka untuk belajar melalui media pun masih terbatas.

"Saya termasuk orang yang ketat memberlakukan jam penggunaan media digital, karena anak saya masih berumur 5 tahun. Dalam sehari hanya saya bolehkan memainkan ipadnya selama 2 jam saja. Lagian belum ada tugas yang membutuhkan informasi dari internet. Beruntung TK nya berada di komplek perumahan ini, jadi gurunya mendatangi rumah dengan mengumpulkan dua hingga tiga murid yang rumahnya berdekatan untuk bermain Bersama. Seusia anak saya sangat membutuhkan interaksi sosial dan bermain-main." (Wawancara FE, ibu rumah tangga, umur 28 tahun).

Berbeda halnya dengan konten, orangtua menerapkan pengaturan yang berbeda-beda. Dua informan mengakui tidak secara detail menjelaskan kepada anak-anaknya mengenai konten apa saja yang tidak boleh di lihat dan aplikasi apa saja yang tidak boleh diakses. Satu informan mengaku hanya memberi penjelasan bila anaknya bertanya saja, jika anaknya tidak meminta penjelasan maka ia lebih memilih diam. Sedangkan lima informan lain secara detail membahas aturan mengenai konten dan aplikasi termasuk mendiskusikan rating sebuah aplikasi ketika anaknya ingin mengakses suatu aplikasi. Hanya satu informan yang mengakui tidak perlu memberi penjelasan terlebih dahulu kepada anaknya, karena menganggap anaknya bisa membedakan mana yang baik dan buruk untuk dirinya.

"Saya tidak terlalu banyak mengatur akses pada konten-konten dan aplikasi tertentu. Pikir saya, pada saat jam pelajaran berlangsung, agak sulit buat anak saya membagi konsentrasi. Saya kadang hanya melihat hasil nilai ulangannya saja. Kalau nilainya bagus berarti belajarnya penuh konsentrasi. Anak saya tidak pernah mengeluh tentang kesulitan penguasaan aplikasi-aplikasi di laptopnya." (Wawancara HA, guru SMP, umur 36 tahun).

Berkaitan dengan diskusi yang dilakukan oleh informan dan anak untuk menegosiasikan penggunaan media, biasanya dilakukan pada saat senggang. Pembicaraan tersebut mengaitkan dengan norma agama dan nilai moralitas. Diskusi tersebut dilakukan sebagai upaya agar anakanak mereka mendapatkan pemahaman dan menjadi semacam self-cencorship bagi anak-anak ketika menggunakan media digital. Selain itu untuk menciptakan kehangatan hubungan orangtua dan anak, dan menumbuhkan kepercayaan dan tanggung jawab pada diri anak-anak mereka.

“Bagi saya, memberikan pemahaman tentang norma agama dikaitkan dengan larangan mengakses konten-konten pornografi, aksi kekerasan, dan bullying sangatlah 
penting. Karena kalau kita membaca pengalaman parenting di negara-negara maju dan banyak terjadi aksi kekerasan, orangtua banyak yang mengabaikan tentang pendidikan agama bagi anak. Mereka hanya percaya pada institusi sekolah dan kadang penitipan anak. Anak-anak membutuhkan orangtua untuk menjadi partner diskusi tentang banyak hal. Dan itulah yang saya perankan ketika anak-anak menggunakan media digital." (Wawancara DR, ASN di Dinas milik Pemprov Jawa Timur, umur 40 tahun).

Model pendampingan media lain yang diterapkan oleh orangtua adalah memonitor aktivitas yang berkaitan dengan media digital melalui history. Selain mengecek history akses internet pada mesin pencari, para informan juga mengecek akun sosial media anaknya untuk memastikan bahwa mereka tidak melakukan hal-hal yang tidak pantas seperti mengakses pornografi, konten dengan kekerasan atau berbohong pada orangtua. Penggunaan aplikasi parental control untuk memblokir situs-situs yang dianggap tidak layak, dinilai tidak berjalan efektif. Anak-anak sekarang jauh lebih pintar untuk mencari cara lain, dan justru menjadikan anak tidak jujur untuk mencari cara membuka blokir pada aplikasi parental control. Cara yang dinilai efektif adalah sering melakukan diskusi untuk membangun kepercayaan antara orangtua dan anak. Serta perlunya menyepakati rambu-rambu dan mempercayakan pada anak-anak untuk berkativitas dengan media digital.

Pandemi COVID-19 telah menyediakan waktu yang lebih banyak bagi jutaan orang di dunia, tinggal bersama keluarga. Ketika kegiatan berpusat di rumah, mulai dari pekerjaan sampai sekolah, hal tersebut memungkinkan orangtua dan anak-anak melakukan aktivitas bersama-sama dalam rentang waktu yang panjang. Demikian pula yang terjadi pada para informan penelitian ini, mereka sesekali menggunakan media digital bersama anak-anaknya. Empat informan mengakui bahwa mereka menggunakan media digital bersama-sama anakanak untuk menonton hiburan, seperti Youtube, TikTok, atau video lucu yang ditemukan dari share di WhatsApp. Dua informan menggunakan media digital bersama anak-anak untuk mempelajari dan menggunakan menu dan fasilitas yang terdapat dalam Learning Manajemen System (LMS) yang dikembangkan oleh kampus dan Kementerian Pendidikan dan Kebudayaan. Kedua informan banyak dibantu oleh anak-anaknya dalam pembuatan media pengajaran berupa video. Satu orang informan belajar memaksimalkan Instagram dari anaknya untuk mempromosikan kue dan makan ringan buatannya.

Persepsi orangtua mengenai media digital memberikan pengaruh terhadap bagaimana orangtua bersikap dalam pendampingan anak dalam penggunaan media digital. Orangtua yang aware terhadap potensi positif dan negatif cenderung memberikan kontrol yang lebih ketat, sementara orangtua yang percaya bahwa media digital mempunyai manfaat positif tanpa potensi negatif selain bahaya kesehatan, cenderung melakukan pengawasan yang longgar. Orangtua yang menyadari potensi negatif dan positif, memiliki kecenderungan untuk menegosiasikan penggunaan digital dengan anak-anaknya sesuai dengan kebutuhan. Orang tua memiliki peran yang penting dalam membentuk pola penggunaan media pada anak (Kristianto, 2017).

Penelitian ini secara spesifik menemukan orangtua perempuan (Ibu) lebih banyak berperan dalam melakukan pengawasan terhadap anak-anak dalam menggunakan media 
digital, daripada orangtua laki-laki (Ayah). Ayah berperan mengawasi penggunaan media digital anak-anaknya, ketika ibu berhalangan. Bahkan ibu lah yang melakukan diskusi dan negosiasi dengan anak-anak tentang berbagai aturan-aturan penggunaan media digital dengan mengembangkan sikap hangat kepada anak (Brito, 2017). Sedikitnya keterlibatan ayah dalam keluarga merupakan hal yang dianggap wajar di Indonesia, karena ibu dianggap sebagai pemegang peranan utama dalam hal pengasuhan anak dan urusan rumah tangga sedangkan ayah merupakan bertanggung jawab untuk memenuhi kebutuhan keluarga (Kusuma dan Tutiasri, 2016).

Penelitian ini mengungkap adanya pergeseran model pendampingan orangtua tentang penggunaan media digital pada anak-anak. Kondisi pandemi menjadikan orangtua sebagai sosok yang mampu bernegosiasi dengan anak dalam penggunaan media digital. Orangtua tidak lagi menerapkan aturan yang ketat, dan tidak bersikap otoriter mengatur penggunaan media digital bagi anak-anaknya. Orangtua menunjukan sikap lebih toleran terutama pada anak-anak berusia di atas 12 tahun, dan cenderung melakukan pengawasan longgar ketika media digital digunakan untuk kegiatan pembelajaran. Hal ini dapat terjadi, karena orangtua masa sekarang lebih melek terhadap metode parenting. Sebelum pandemi, penggunaan media digital oleh anak diatur secara ketat oleh orangtua. Pembatasan penggunaan media digital lebih bersifat teknis, yaitu membatasi waktu dan pilihan konten. Selama masa pandemi, orangtua menerapkan aturan yang lebih longgar, dengan alasan bahwa anak-anak memerlukan perangkat tersebut untuk kebutuhan SFH, pemenuhan kebutuhan interaksi sosial, dan menghindari rasa bosan tinggal di rumah.

Adanya realitas tingginya penggunaan media digital pada anak di masa pandemi, selayaknya diimbangi dengan pendampingan yang memadai dari kedua orangtua. Kedua orangtua harus secara aktif berdiskusi dengan anak-anak, dan turut merasakan sensasi menggunakan media digital bersama-sama anak-anak, dengan tujuan untuk menumbuhkan daya pikir kritis anak terhadap dampak positif dan negatif pesan-pesan yang terdapat dalam media digital. Sebagaimana argumentasi Venta-Olkonnen (2020) yang menyatakan bahwa kemampuan berpikir kritis dan pandangan yang proaktif membantu anak-anak membangun realitas sosialnya dengan memahami bagaimana sesuatu seharusnya dan bagaimana sesuatu bisa terjadi. Sehingga anak terhindar dari sikap open-receptive atau menerima mentah-mentah terhadap isi pesan yang disampaikan melalui media digital. Untuk itulah, orangtua-gurusekolah memiliki peranan penting dalam pembentukan kemampuan generasi muda untuk memiliki keterampilan melek digital. Dan peran terpenting dalam mengembangkan kemampuan kritis tersebur dimiliki oleh para orangtua (Livari, Sharma dan Venta-Olkkonen, 2020). Manfaat dalam penggunaan media digital secara bersama oleh orangtua dan anak-anak usia 1-15 tahun adalah mampu merangsang interaksi sosial anak dan melatih respon anak dalam lingkungan sosial yang nyata. Penggunaan bersama tersebut dapat diterapkan, misalnya dalam aktivitas membaca bersama dengan menggunakan perangkat digital, memainkan permainan yang melibatkan interaksi antara orangtua dan anak. Bermain bersama antara orangtua dan anak sangat berpengaruh bagi pengembangan respon anak untuk melakukan interaksi sosial. Usia anak-anak adalah masa terpenting untuk melakukan permainan bersama, 
karena fokus anak-anak usia dini adalah bermain (Kirkorian, Pempek, Murphy, Schmidt, \& Anderson, 2009; Georgene L. Troseth, Colleen E. Russo \& Gabrielle A. Strouse, 2016).

Para informan yang mewakili profil orangtua di kota Surabaya, menerapkan model pendampingan yang bervaritaif, tidak fokus pada satu model, mulai dari restrictive berupa pembatasan aturan waktu dan konten, active mediation dengan berdiskusi, co-using dengan menggunakan bersama antara orangtua dengan anak-anak, supervision dengan mengawasi secara langsung penggunaan media, memonitor aktifitas yang telah dilakukan melalui history dan mengecek akun sosial media dan menggunakan pembatasan teknis dengan menerapkan parental controls aplikasi. Namun dari ke enam hal yang dilakukan, orangtua masih terbatas dalam melakukan diskusi untuk meningkatkan kemampuan kritis dan pembelajaran, pendampingan media yang dilakukan baru berfungsi sebagai bentuk kontrol dan pengawasan supaya anak-anak tidak terpapar konten atau aktivitas yang tidak pantas. Apabila merujuk pada model pendampingan media digital menurut Valcke et al. (2010), sebagian besar orangua menerapkan model authoritative, authoritarian dan permissive. Bahkan tidak ada satupun orangtua yang menerapkan model laissez fairre, atau memberi kebebasan penuh pada anak untuk menggunakan media digital. Begitu pula dalam penelitian ini, tidak ada satupun orangtua yang mengadopsi model laissez faire. Hal ini menunjukan bahwa orangtua menganggap bahwa penggunaan media digital merupakan hal yang penting untuk diperhatikan.

\section{Simpulan}

Penelitian ini menemukan bahwa terdapat peningkatan waktu penggunaan media digital yang signifikan pada keluarga dengan anak 1-15 tahun di Surabaya. Para orangtua telah menerapkan pengawasan dan pendampingan dalam penggunaan digital media pada anak. Namun selama masa pandemic COVID-19, telah terjadi pergeseran model pengawasan yang dilakukan oleh orangtua yaitu menjadi lebih longgar, hal ini dilakukan dengan alasan pemenuhan kebutuhan pembelajaran daring, memenuhi kebutuhan anak untuk bersosialisasi dan berinteraksi sosial, serta untuk menghilangkan kebosananan akibat lama tinggal di rumah.

Orangtua menerapkan beberapa model pendampingan penggunaan media digital pada anak. Model yang paling banyak diterapkan adalah dengan melakukan pembatasan waktu dan konten, membangun kesepakatan dan berdiskusi untuk membangun keterbukaan dan kehangatan. Penggunaan aplikasi parental kontrol dan pengecekan history pun diterapkan. Pembatasan yang lebih ketat mengenai waktu dan konten diterapkan kepada anak dengan usia di bawah 8 tahun. Sementara anak yang berusia di atas 12 tahun, cenderung diberikan toleransi karena untuk kepentingan sekolah dan karena orangtua merasa bahwa anak telah memahami mana yang baik dan buruk untuk diri mereka sendiri. Masa pandemi telah menyediakan ruang bagi orangtua dan anak untuk menggunakan media secara bersama-sama terutama untuk berbagi hiburan. Selain itu juga memberikan kesempatan pada orangtua untuk mempelajari keterampilan teknologi digital dari anak-anaknya yang mempunyai keterampilan digital lebih baik dibandingkan orangtua. 


\section{Ucapan Terimakasih:}

Para penulis mengucapkan terimakasih kepada panitia dan reviewer Konferensi Media Digital (Komedi) 2020, Program Studi IImu Komunikasi UPN Veteran Jawa Timur serta editor dan reviewer Journal of Media and Communication Science, Program Studi Ilmu Komunikasi Universitas Mataram Lombok.

\section{Daftar Pustaka}

AAP Council on Communication and Media. (2016). Media and young mind. Pediatrics. 138(5). retrieved from: https://pediatrics.aappublications.org/content/pediatrics/138/5/e20162591.full.pdf

Alamiyah S.S., Zamzamy A., Rasyidah, R. (2017). Literacy Media Counseling Program, Increasing Parent Skill on Parental Mediation and Parental Gadget Co-Viewing on Students of Al-Hikmah Suko Sidoarjo. International Seminar of Research Month and Technology in Publication, Implementation and Commercialization. NST Proceedings. pages 369-376.doi: 10.11594/nstp.2018.0154.

Alamiyah S.S., Zamzamy A., Rasyidah, R. (2018). Media literacy program for early childhood teacher to enhance childrencritical thinking skills in Sidoarjo. International Seminar of Research Month Science and Technology for People Empowerment. NST Proceedings. pp 513-519. doi: 10.11594/nstp.2019.0270.

Brito, R., Francisco, R., Dias, P., \& Chaudron, S. (2017). Family dynamics in digital homes: the role played by parental mediation in young children's digital practices around 14 European countries. Contemporary Family Therapy. 39. pp. 271-280. doi: 10.1007/s10591-017-9431-0

Cellini, N., Canale, N., Mioni, G, \& Costa, S. (2020). Changes in sleep pattern, sense of time and digital media use during COVID-19 lockdown in Italy. J Sleep Res. 2020;29:e13074. https://doi.org/10.1111/jsr.13074

Hendriyani, Hollander, E., d'Haenens, L., \& Beentjes, J. (2014). Views on children's media use in Indonesia: Parents children, and teachers. International Communication Gazette. 76(322). doi: 10.1177/1748048514523527

Hendriyani, Hollander, E., d'Haenens, L., \& Beentjes, J. (2012). Children's media use in Indonesia. Asian Journal of $\begin{array}{llll}\text { Communication, } & \text { 22(3). } & \text { 304-319. }\end{array}$ https://eresources.perpusnas.go.id:2116/10.1080/01292986.2012.662514

Indiyati, D.I., Khusnia, H.N., \& Chotijah, S. (2020). Media vs kepercayaan publik di masa pandemi. Jcommsci (Journal of Media and Communication Science). 3(special issue). pp. 38-44.

Kirkorian, H.L., Pempek, T.A., Murphy, L.A., Schmidt, M.E., \& Anderson, D.R. (2009). The impact on background television on parent-child interaction. Child Development. 8(5) pp. 1350- 1359. retrieved from https://www.researchgate.net/publication/26822512_The_Impact_of_Background_Television_on_Pare nt-Child_Interaction/link/5a1c3ca645851514b5305009/download

Kristianto, B. (2017). Factors affecting social network use by students in Indonesia. Journal of Information Technology Education: Research. 16, pp. 69-103 retrieved from http://www.informingscience.org/Publications/3675

Kusuma, A., \& Puspita, R. (2016). Family identity in Indonesian films (interpersonal communications between fathers, who are transgender or transsexual, and their children). International Journal of Soial and Humanity. 6(1). pp. 77-80. doi: 10.7763/IJSSH.2016.V6.662

Lau, E.Y.H., \& Lee, K. (2020). Parent's views on young children's distance learning and screen time during Covid19 class suspension in Hong Kong. Early Education and Development. doi: 10.1080/10409289.2020.1843925

Livari, N., Sharma, S., \& Venta-Olkkonen, L. (2020). Digital transformation of everyday life - How Covid-19 pandemic transformed the basic education of the young generation and why information managemet research could care?. International Journal of Information Management, 55(2020), https:??doi.org/10.1016/j.ijinfomgt.2020.102183

Livingstone, S. (2020, Oktober 12). Parenting for a digital future: how hopes and fears about technology shape children's lives. dipresentasikan pada Zoom Webinar Research Round Table Online.

Livingstone, S., \& Helsper, E. (2008). Parental mediation and children's Internet use. Journal of broadcasting and electronic media. 52(4). pp. 581-599. doi: 10.1080/08838150802437396

Livingstone, S., \& Bober, M. (2004). UK children go online: Surveying the experiences of young people and their parents. Accessed from https://www.york.ac.uk/res/e-society/projects/1/UKCGOsurveyreport.pdf

Miranda, D.M., Athanasio, B.S., Oliveira, A.C.S., \& Simoes-e-Silva, A.C. (2020). How is Covid-19 pandemic impacting mental health of children and adolescents? International Journal of Disaster Risk Reduction. 51(2020). doi: 10.1016/j.ijdrr.2020.101845 
Moleong, L. (2005). Metode Penelitian Kualitatif. Bandung: PT. Remaja Rosdakarya.

Saptyasari, A. (2020, September 22). Pergeseran komunikasi keluarga selama masa pandemi. dipresentasikan pada Zoom Webinar Digital Family: Pergeseran Lanskap Komunikasi Keluarga Selama Di rumah Saja. Departemen Komunikasi UNAIR

Shin, W., \& Li, B. (2016). Parental mediation of children's digital technology use in Singapore. Journal of Children and Media. doi: 10.1080/17482798.2016.1203807

Troseth, G.L., Russo, C.E., \& Strouse, G.A. (2016). What's next for research on young children's interactive media. Journal of children and Media. 10(1). pp 54-62. doi: 10.1080/17482798.205.1123166

Valcke, M., Bonte, S., Wever, B. De, \& Rots, I. (2010). Internet parenting styles and the impact on internet use of primary school children. Journal of Computer and Education. 55(2010) pp. 454-464. doi: 10.1016/j.compedu.2010.02.009

Valkenburg, P.M., Krcmar, M., Peeters, A.L., \& Marseille, N.M. (1999). Developing a scale to assess three styles of television mediation: "Instructive mediation," "restrictive mediation", and "social coviewing". Journal of Broadcasting \& electronic Media. 43(1). pp. 52-66. doi: 10.1080/08838159909364474

Wai WONG C, TSAI A, Jonas JB, Ohno-Matsui K, CHEN J, ANG M, Wei TING DS, Digital Screen Time During COVID19 Pandemic: Risk for a Further Myopia Boom?, American Journal of Ophthalmology (2020), doi: https://doi.org/10.1016/j.ajo.2020.07.034.

Wiederhold, B. (2020). Children's screen time during the Covid-19 pandemic: boundaries and etiquette. Cyberpsychology, Behaviour, and Social Networking. 6 (3). pp. 359-360. doi: 10.1089/cyber.2020.29185.bkw

Wong, C.A., Ming, D., Maslow, G., et al. (2020). Mitigating the impacts of the COVID-19 pandemic response on AtRisk children, Pediatrics. 146(1) e20200973 retrieved from https://pediatrics.aappublications.org/content/146/1/e20200973

Wong, C.W., Tsai, A., Jonas, J.B., Ohno-Matsui, K., Chen, J., Ang, M., \& Ting, D.S.W. (2020). Digital screen time during covid-19 pandemic: Risk for a further myopia boom?. American Journal of Ophthalmology. https://doi.org/10.1016/j.ajo.2020.07.034 